\title{
Studies on $N^{5}$-Methyltetrahydrofolate-Homocysteine Methyltransferase in Normal and Leukemic Leukocytes
}

\author{
Renate Peytremann, Janet Thorndike, and William S. Beck \\ From the Department of Medicine, Harvard Medical School, and the \\ Hematology Research Laboratory of the Massachusetts General Hospital, \\ Boston, Massachusetts 02114
}

\begin{abstract}
A B S T R A C T A cobalamin-dependent $N^{5}$-methyltetrahydrofolate-homocysteine methyltransferase (methyltransferase) was demonstrated in unfractionated extracts of human normal and leukemic leukocytes. Activity was substantially reduced in the absence of an added cobalamin derivative. Presumably, this residual activity reflects the endogeneous level of holoenzyme. Enzyme activity was notably higher in lymphoid cells than in myeloid cells. Thus, mean specific activities ( $\pm \mathrm{SD})$ were: chronic lymphocytic leukemia lymphocytes, $2.15 \pm 1.16$; normal lymphocytes, $0.91 \pm 0.59$; normal mature granulocytes, $0.15 \pm 0.10$; chronic myelocytic leukemia granulocytes, barely detectable activity. Properties of leukocyte enzymes resembled those of methyltransferases previously studied in bacteria and other animal cells. Granulocytes and chronic myelocytic leukemia cells contain a factor or factors that inhibits Escherichia coli enzyme. The data suggest that the prominence of this cobalamin-dependent enzyme in lymphocytes and other mononuclear cell types may be related to their potential for cell division.
\end{abstract}

\section{INTRODUCTION}

Many studies have shown that the final step in the cobalamin-dependent pathway of methionine synthesis in bacteria and in animal cells is catalyzed by $N^{\mathrm{s}}$-methyltetrahydrofolate-homocysteine methyltransferase (methyltransferase) ${ }^{1}$ according to equation 1 (reference 1 ) :

Dr. Peytremann's present address, Division of OncoHematology, Department of Medicine, Hôpital Cantonal, Geneva, Switzerland.

Received for publication 3 September 1974 and in revised form 14 July 1975.

1 Abbreviations used in this paper: ALL, acute lymphocytic leukemia; $\mathrm{CH}_{3}-\mathrm{FH}_{4}, N^{5}$-methyltetrahydrofolate; $\mathrm{CLL}$ chronic lymphocytic leukemia; CML, chronic myelocytic leukemia; $\mathrm{FH}_{4}$, tetrahydrofolate; methyltransferase, $N^{5}$ methyltetrahydrofolate-homocysteine methyltransferase; $\mathbf{M}$ -

$$
\begin{aligned}
\mathrm{CH}_{3}-\mathrm{FH}_{4}+\text { L-homocysteine } & \frac{\text { reducing system }}{\text { cobalamin, SAM }} \\
& \mathrm{FH}_{4}+\text { methionine. }
\end{aligned}
$$

Analogous enzymes have been characterized in Escherichia coli (2-4) and in various cells of animal origin (5-15). Some evidence suggests that a major function of the enzyme is the maintenance of methionine levels in tissues. According to other evidence, the pathway has an essential role in producing $\mathrm{FH}_{4}$, which can enter into essential transfers of "one-carbon" units in various other pathways, e.g., the folate-dependent synthesis of thymidylate (16). Doubtless, both views are correct, the relative importance of the two functions differing perhaps under different conditions.

Despite extensive discussion of an hypothesis that gives this pathway critical importance in the impairment of DNA synthesis associated with the megaloblastosis of vitamin $B_{12}$ deficiency (reviewed in reference 17), little is known of the distribution and characteristics of methyltransferase in human blood cells. This lack has motivated the present investigation. Human leukocytes were chosen for study since they include cells that are grossly altered morphologically by vitamin $\mathrm{B}_{12}$ deficiency (granulocytes) and cells that are not (lymphocytes); certainly though, evidence is available to suggest that vitamin $\mathrm{B}_{12}$ deficiency has effects on the immunologic function $(18,19)$ and chromosomal patterns $(20,21)$ of lymphocytes.

In the present study, methyltransferase activity was assayed in crude extracts of isolated granulocytes and lymphocytes, and kinetic properties of the enzymes in these extracts were characterized. The data show that lymphocytes contain higher enzyme levels than granulocytes, that lymphocytes from subjects with chronic lym-

ML, myelomonocytic leukemia; PBS, potassium phosphate buffer, $10 \mathrm{mM}, \mathrm{pH} 7.4$, in $0.9 \% \mathrm{NaCl} ; \mathrm{PV}$, polycythemia vera; SAM, $S$-adenosylmethionine. 
phocytic leukemia (CLL) had even higher enzyme levels than normal lymphocytes, and that granulocytes contain one or more factors that inhibit methyltransferase activity.

\section{METHODS}

Reagents. Chemicals were obtained from the following sources: L-homocysteine thiolactone hydrochloride, $S$-adenosylmethionine chloride, folic actd, soybean and beef pancreas trypsin inhibitors, and bovine pancreas trypsin from Sigma Chemical Co., St. Louis, Mo., casein (Hammarsten quality) from Nutritional Biochemicals Corp., Cleveland, Ohio; cyanocobalamin and hydroxycobalamin from SchwarzMann Div., Becton, Dickinson \& Co., Orangeburg, N. Y.; deoxyadenosylcobalamin from Calbiochem, San Diego, Calif. Samples of methylcobalamin were kindly provided by Dr. Bernard M. Babior, New England Medical Center, Boston, and Dr. Robert H. Abeles, Brandeis University, Waltham. Propylcobalamin was synthesized by reduction of cyanocobalamin with sodium borohydride, followed by alkylation with propyl bromide. The product was isolated by thinlayer chromatography on silica gel, using propanol: water: ammonium hydroxide $(100: 99: 1)$ as solvent system (22). Nonradioactive $d, l-\mathrm{CH}_{3} \mathrm{FH}_{4}$, synthesized according to Blair and Saunders (23), was purified by DEAE-cellulose chromatography according to Gupta and Huennekens (24). $N^{5}$ $\left[{ }^{14} \mathrm{C} \mathrm{CH}_{3}-\mathrm{FH}_{4}\right.$ was purchased from Amersham/Searle Corp., Arlington Heights, Ill. Both products were chromatographically homogeneous and stable when stored under $\mathrm{N}_{2}$ at $-20^{\circ} \mathrm{C}$ for $1 \mathrm{yr}$.

L-Homocysteine thiolactone hydrochloride was converted to L-homocysteine by exposure to $0.3 \mathrm{M} \mathrm{NaOH}(7-10 \mathrm{~min})$, followed by neutralization with $0.3 \mathrm{M} \mathrm{KH}_{2} \mathrm{PO}_{4}$ (25).

Preparation of lymphocytes and granulocytes. Venous blood (20-100 ml) was drawn from ostensibly normal donors (hospital personnel and patients without blood dyscrasias other than mild leukocytosis) and patients with CLL and other hematologic disorders that were untreated except as noted. Cell morphology in CLL patients studied was primarily that of typical small lymphocytes, without nucleoli, nuclear clefting, or pleomorphism. Normal subjects and CLL patients were not matched for age, the mean ages of the two groups being $26 \pm 4$ and $63 \pm 13 \mathrm{yr}$. Serum prepared from an aliquot of blood was stored at $-10^{\circ} \mathrm{C}$ for assay of serum folate and vitamin $B_{12}$ levels by methods employing Lactobacillus casei (26) and Lactobacillus leichmannii (27). Normal ranges in this laboratory for serum folate are $6-16 \mathrm{ng} / \mathrm{ml}$ and for serum vitamin $B_{12}$ are $150-450 \mathrm{pg} / \mathrm{ml}$. Heparin (Liquaemin sodium, The Upjohn Company, Kalamazoo, Mich.) was used as anticoagulant for blood samples $(10-20 \mathrm{U} / \mathrm{ml})$.

Leukocytes from normal subjects were obtained by mixing blood with 0.1 vol of $6 \%$ dextran and sedimenting erythrocytes for $1 \mathrm{~h}$ at $37^{\circ} \mathrm{C}(28)$. The supernatant fraction was centrifuged at $100 \mathrm{~g}$ to remove platelet-rich plasma and leukocytes were suspended in $0.9 \% \mathrm{NaCl}$. Lymphocytes and granulocytes were then separated in a Hypaque-Ficoll gradient according to Böyum (29) with centrifugation steps as modified by Handin et al. (30).

Collected lymphocytes were washed three times with icecold potassium phosphate buffer (PBS). Granulocytes collected from the pellet of the gradients, after lysis of erythrocytes (with $6 \mathrm{ml} \mathrm{H}_{2} \mathrm{O}$ for $30 \mathrm{~s}$ followed by $2 \mathrm{ml}$ of $3.5 \%$ $\mathrm{NaCl}$ ), were washed twice with PBS. Cell counts and stained smears were prepared from the final suspension. About one to two contaminating platelets and a rare erythrocyte were observed per leukocyte. Final lymphocyte suspensions contained 0-2\% granulocytes in CLL blood and $8-12 \%$ in blood of normal donors. Granulocyte preparations contained less than $5 \%$ lymphocytes.

Lymphocytes and granulocytes were then suspended in 3-8 vol of $20 \mathrm{mM}$ PBS, $\mathrm{pH} 7.4$ with $1 \mathrm{mM} \beta$-mercaptoethanol and disrupted for $60 \mathrm{~s}$ in a cooled 18-20 kcycle MSE ultrasonic disintegrator (Measuring \& Scientific Equipment Ltd., London). Phase microscopy showed essentially complete disruption. Sonic extracts were centrifuged at $27,000 \mathrm{~g}$ for $30 \mathrm{~min}$, and supernatant fractions were assayed for methyltransferase. Experiments showed that all activity was recoverable with these fractions.

Leukocytes from the blood of CLL patients with $>80 \%$ lymphocytes or other leukemias were routinely isolated by dextran sedimentation (28) with omission of the HypaqueFicoll gradient. Separate experiments clearly indicated that similar enzyme levels were obtained when the gradient was not omitted. Platelet-rich supernatant fractions were again discarded, erythrocytes were lysed osmotically, and cells were washed twice with PBS. Cell extracts were prepared as described above. Supernatant fractions were assayed for methyltransferase after storage for $18 \mathrm{~h}$ or less at $4^{\circ} \mathrm{C}$ or for longer periods at $-50^{\circ} \mathrm{C}$. Enzyme activity decreased less than $10 \%$ after storage up to 40 days at $-50^{\circ} \mathrm{C}$. When indicated, cell extracts were dialysed for $18 \mathrm{~h}$ against 100 200 vol of $20 \mathrm{mM}$ PBS, $\mathrm{pH} 7.4$, with $1 \mathrm{mM} \beta$-mercaptoethanol.

Preparation of E. coli extracts. E. coli B was grown in minimal essential medium (31) except in experiments in which it was grown in minimal medium containing added $0.01 \mu \mathrm{M}$ cyanocobalamin. Cells were harvested in the logarithmic phase of growth. Cells were suspended in 3 vol of Tris-chloride buffer, $50 \mathrm{mM}, \mathrm{pH} 7.4$, containing $1 \mathrm{mM} \beta$ mercaptoethanol and disrupted for $3 \mathrm{~min}$ in a cooled 18-20 kcycle MSE ultrasonic disintegrator. Cell debris was removed by centrifugation for $30 \mathrm{~min}$ at $27,000 \mathrm{~g}$ at $2^{\circ} \mathrm{C}$. Aliquots of supernatant fractions (termed $E$. coli extract) were stored at $-50^{\circ} \mathrm{C}$ for methyltransferase assay. At this temperature activity remained stable for several months. With each batch of enzyme assays in leukocyte materials, methyltransferase was assayed simultaneously in a control E. coli extract.

Methyltransferase assay and other assays. Methyltransferase was measured as the amount of $\left[{ }^{14} \mathrm{C}\right]$ methionine formed from $N^{5}-\left[{ }^{14} \mathrm{C}\right] \mathrm{CH}_{3}-\mathrm{FH}_{4}$ according to Weissbach et al. (3), with minor modifications (7). The standard assay system contained in a total volume of $0.5 \mathrm{ml}: N^{5}-\left[{ }^{14} \mathrm{C}\right]-$ $\mathrm{CH}_{3}-\mathrm{FH}_{4}, 250 \mu \mathrm{M}$ (sp act, $400 \mathrm{cpm} / \mathrm{nmol}$ ); SAM, 100 $\mu \mathrm{M} ; \mathrm{L}$-homocysteine freshly prepared from the thiolactone hydrochloride, $1.25 \mathrm{mM}$; cyanocobalamin, $100 \mu \mathrm{M} ; \beta$-mercaptoethanol, $200 \mathrm{mM}$; PBS, $50 \mathrm{mM}, \mathrm{pH} \mathrm{7.4;} \mathrm{and} 0.5-1.0$ $\mathrm{mg}$ of leukocyte protein or $0.2-0.3 \mathrm{mg}$ of $E$. coli protein. All incubations were carried out in duplicate. As noted below, parallel assays were ordinarily performed with and without added cyanocobalamin in the incubation mixture. Incubations lacking enzyme were used as blanks.

Standard-type incubations were conducted at $37^{\circ} \mathrm{C}$ for $1 \mathrm{~h}$ in the dark in air. Certain incubations, as indicated below, were conducted in an atmosphere of $\mathrm{N}_{2}$. All reactions were terminated by chilling on ice and addition of $1 \mathrm{ml}$ of ice water. Aliquots of incubation mixtures were passed through $0.5 \times 3-\mathrm{cm}$ Dowex $1-\mathrm{Cl}$ columns (Dow Chemical, Midland, Mich.). Columns were then washed with $2 \mathrm{ml}$ of water. Control experiments demonstrated complete retention of $N^{5}-\left[{ }^{14} \mathrm{C}\right]-\mathrm{CH}_{3}-\mathrm{FH}_{4}$ by columns. Aliquots of total effluent were counted in naphthalene-dioxane scintillation fluid. Specific enzyme activity was expressed as nanomoles methionine formed per milligram of protein 
per hour. In most cases specific activities below 0.1 could not be reliably detected by the assay methods used. Specific activity of various $E$. coli extracts was 108-140. Reaction products of methyltransferase activity in leukocyte and $E$. coli extracts were identified as methionine by chromatography on Dowex $50-\mathrm{H}^{+}$columns and then on Whatman no. 1 paper (butanol:acetic acid: water, 60:15:25) (3, 32). Radioassay of paper chromatogram showed that 88$97 \%$ of the radioactivity in reaction products was in the methionine and methionine sulfoxide regions. The amount of methionine formed increased as a linear function of time with incubation times up to $2 \mathrm{~h}$ in lymphocytes and $E$. coli extracts and as a linear function of enzyme concentration (1-5 $\mathrm{mg}$ protein for lymphocyte extracts, 0.3$1.0 \mathrm{mg}$ for $E$. coli extracts). $K_{m}$ values were calculated by the Lineweaver-Burk method (33).

Protease activity was measured as described by Laskowski with casein as substrate (34). Protein was determined by a modification of the microbiuret method (35). Routine hematological data were obtained by standard methods.

\section{RESULTS}

Methyltransferase activity in leukocytes. Striking differences were observed in the methyltransferase activity of different classes of leukocytes (Tables I and
II). Specific activity in lymphocytes from normal subjects in the standard assay system was $0.91 \pm 0.39$ (Table II). Lymphocytes from patients with CLL had a higher mean specific activity, the difference from normal lymphocytes being statistically significant $(P=$ $<0.001)$. Repeated determinations of enzyme activity on different blood samples from normal subjects and leukemic patients showed variations of less than $10 \%$ of the mean. Mixtures of normal lymphocyte and CLL extracts gave results predictable from the sums of their separate activities.

Cells from a child with acute lymphocytic leukemia (ALL) (patient 19) showed activity intermediate between that of normal and CLL lymphocytes. Similar values were found in lymphocytes of a patient with Sézary syndrome.

Omission of exogenous cyanocobalamin decreased the activity of methyltransferase in normal and CLL lymphocytes by about $65 \%$. Even in the absence of added cyanocobalamin, the difference between normal and CLL cells was significant $(P=<0.01)$. Only traces

TABLE I

Patients Studied

\begin{tabular}{|c|c|c|c|c|c|c|c|c|c|c|c|}
\hline \multirow[b]{2}{*}{$\begin{array}{l}\text { Patient } \\
\text { no. }\end{array}$} & \multirow[b]{2}{*}{ Diagnosis } & \multirow[b]{2}{*}{$\begin{array}{l}\text { Hemato- } \\
\text { crit }\end{array}$} & \multirow[b]{2}{*}{$\begin{array}{c}\text { Leuko- } \\
\text { cytes } \\
\left(\times 10^{3}\right)\end{array}$} & \multirow[b]{2}{*}{ Blasts } & \multirow[b]{2}{*}{$\begin{array}{l}\text { Neutro- } \\
\text { phils }\end{array}$} & \multirow[b]{2}{*}{$\begin{array}{l}\text { Mono- } \\
\text { cytes }\end{array}$} & \multirow[b]{2}{*}{$\begin{array}{l}\text { Lympho- } \\
\text { cytes }\end{array}$} & \multirow[b]{2}{*}{$\begin{array}{c}\text { Serum } \\
\text { vitamin } \\
B_{12}\end{array}$} & \multirow[b]{2}{*}{$\begin{array}{l}\text { Serum } \\
\text { folate }\end{array}$} & \multicolumn{2}{|c|}{$\begin{array}{c}\text { Methyltransferase, } \\
\text { sp act }\end{array}$} \\
\hline & & & & & & & & & & $\begin{array}{c}\text { Cyanoco- } \\
\text { balamin } \\
\text { added }\end{array}$ & $\begin{array}{c}\text { Cyanoco } \\
\text { balamin } \\
\text { omitted }\end{array}$ \\
\hline & & $\%$ & $m m^{3}$ & & & $7_{0}$ & & $p g / m l$ & $n g / m l$ & \multicolumn{2}{|c|}{$\begin{array}{c}\text { nmol methionine } \cdot m g \\
\text { protein }{ }^{-1} \cdot h^{-1}\end{array}$} \\
\hline 1 & CLL & 38 & 38 & 0 & 18 & 2 & 74 & 340 & 16.1 & 2.48 & 1.01 \\
\hline 2 & CLL & 37 & 42 & 0 & 28 & 7 & 63 & 430 & 9.4 & 2.34 & 0.84 \\
\hline 3 & CLL & 31 & 22 & 0 & 17 & 1 & 82 & 310 & 10.5 & 1.68 & 0.50 \\
\hline 4 & CLL & 33 & 21 & 0 & 9 & 1 & 90 & 410 & 7.2 & 1.72 & 0.56 \\
\hline 5 & CLL* & 44 & 26 & 0 & 7 & 1 & 91 & 450 & 14.4 & 5.78 & 1.98 \\
\hline 6 & CLL & 34 & 160 & 0 & 9 & 3 & 86 & 335 & 4.8 & 1.65 & 0.62 \\
\hline 7 & CLL & 27 & 59 & 0 & 5 & 2 & 90 & 540 & 7.2 & 0.64 & 0.24 \\
\hline 8 & CLL & 25 & 102 & 0 & 3 & 0 & 97 & 380 & 11.6 & 2.09 & 0.68 \\
\hline 9 & CLL $\ddagger$ & 26 & 77 & 0 & 2 & 1 & 97 & 270 & $>40$ & 1.93 & 0.55 \\
\hline 10 & CLL & 46 & 22 & 0 & 11 & 2 & 87 & 320 & 13.2 & 1.91 & 0.71 \\
\hline 11 & CLL & 41 & 68 & 0 & 7 & 1 & 92 & 300 & 6.3 & 3.25 & 1.05 \\
\hline 12 & CLL & 35 & 46 & 0 & 0 & 0 & $1 \mathrm{co}$ & 110 & 34.2 & 3.01 & 0.76 \\
\hline 13 & CLL & 29 & 239 & 0 & 2 & 0 & 97 & 275 & 18.6 & 1.93 & 0.83 \\
\hline 14 & CLL & 46 & 34 & 0 & 16 & 0 & 83 & $21 \mathrm{C}$ & 23.4 & 0.55 & 0.08 \\
\hline 15 & CLL & 49 & 33 & 0 & 9 & 0 & 89 & 310 & 4.2 & 1.95 & 0.59 \\
\hline 16 & CLL & 34 & 90 & 0 & 6 & 0 & 93 & 170 & 13.6 & 1.46 & 0.38 \\
\hline 17 & CLL & 36 & 80 & 0 & 1 & 6 & 93 & 160 & 6.7 & 2.15 & 0.58 \\
\hline 18 & $\begin{array}{l}\text { Sézary } \\
\text { syndrome§ }\end{array}$ & 40 & 46 & 0 & 14 & 0 & 85 & 200 & 6.3 & 1.32 & 0.30 \\
\hline 19 & ALL & 24 & 29 & 94 & 5 & $\mathbf{0}$ & 0 & 325 & 16.8 & 1.51 & 0.29 \\
\hline 20 & CML & 42 & 36 & 2 & 39 & 8 & 5 & $>1,000$ & 13.8 & 0.21 & 0.06 \\
\hline 21 & CML & 44 & 33 & $\mathbf{0}$ & 60 & 3 & 4 & $>1,000$ & 10.0 & 0.19 & 0.05 \\
\hline 22 & CML & 40 & 77 & 0 & 53 & 1 & 4 & 500 & 10.2 & 0.00 & 0.00 \\
\hline 23 & CMLף & 26 & 138 & 70 & 8 & 2 & 3 & $>1,000$ & 6.4 & 2.01 & 0.47 \\
\hline 24 & PV & 54 & 22 & 0 & 83 & 5 & 8 & 420 & 9.4 & 0.19 & 0.07 \\
\hline 25 & MML & 34 & 68 & 39 & 20 & 30 & 7 & 170 & 8.0 & 0.63 & 0.18 \\
\hline 26 & MML & 32 & 78 & 0 & 17 & 77 & 4 & 270 & 2.6 & 0.58 & 0.11 \\
\hline
\end{tabular}

* Patient receiving prednisone, $7.5 \mathrm{mg} / \mathrm{day}$.

Patient receiving folic acid.

\$ Surface properties of lymphocytes were investigated by Dr. A. C. Aisenberg. Absence of surface immunoglobulins, positivity for thymus-specific surface markers in $92 \%$ of the cells, and other parameters were consistent with $\mathrm{T}$-cell origin.

II In blastic crisis. 
TABLE II

Methyltransferase Activity in Extracts of Leukocytes*

\begin{tabular}{llccc}
\hline & & & \multicolumn{2}{c}{ Methyltransferase, sp act } \\
\cline { 4 - 5 } Cell type(s) & \multicolumn{1}{c}{ Diagnosis } & Subjects & $\begin{array}{c}\text { Cyanocobalamin } \\
\text { added }\end{array}$ & $\begin{array}{c}\text { Cyanocobalamin } \\
\text { omitted }\end{array}$ \\
\hline & & $n$ & $n$ nol methionine $\cdot$ mg $_{\text {protein }}{ }^{-1} \cdot h^{-1}$ \\
Lymphocytes & Normal & $(7)$ & $0.91 \pm 0.39$ & $0.34 \pm 0.21$ \\
Lymphocytes & CLL & $(17)$ & $2.15 \pm 1.16$ & $0.72 \pm 0.41$ \\
Lymphocytes & Sézary syndrome & $(1)$ & 1.32 & 0.30 \\
Lymphocytes & ALL & $(1)$ & 1.51 & 0.29 \\
Granulocytes & Normal & $(11)$ & $0.15 \pm 0.10$ & $0.09 \pm 0.09 \ddagger$ \\
Granulocytes & CML & $(3)$ & 0.13 & 0.04 \\
Mixed & CML§ & $(1)$ & 2.01 & 0.47 \\
Mixed & PV & $(1)$ & 0.19 & 0.07 \\
Mixed & MML & $(2)$ & 0.61 & 0.15 \\
\hline
\end{tabular}

* Figures represent specific activities of methyltransferase in leukocyte extracts as described in text. Values are means $\pm \mathrm{SD}$. When indicated $50 \mathrm{nmol}$ of cyanocobalamin was added to incubation mixture.

$\ddagger$ Mean of only five determinations

$\S$ In blastic crisis.

of methyltransferase activity were detected in normal granulocytes and cells from patients with chronic myelocytic leukemia (CML) and polycythemia vera (PV) when assayed in the standard system with up to $2.0 \mathrm{mg}$ of protein per incubation. Enzyme in those cells was virtually undetectable when assayed without added cy-

TABLE III

Requirements of Methyltransferase System in CLL Extracts*

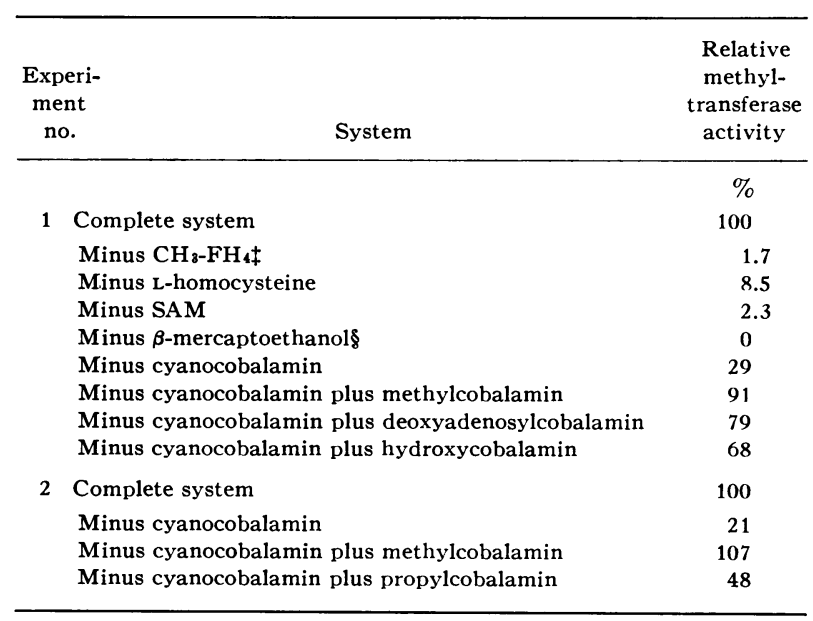

* Figures represent relative specific activities. Activity with the complete sytem is designated $100 \%$. Actual specific activities in the complete systems in exps. 1 and 2 were 3.42 and 1.87 , respectively. When shown, $50 \mathrm{nmol}$ of the indicated cobalamin derivative was added per incubation.

$\ddagger$ Reaction mixture contained $0.5 \mathrm{nmol}$ of $N^{5}-\left[{ }^{14} \mathrm{C}\right]-\mathrm{CH}_{3}-\mathrm{FH}_{4}$

$\$$ Reaction mixture still contained $11 \mathrm{nmol}$ of $\beta$-mercaptoethanol added with $\mathrm{CH}_{3}-\mathrm{FH}_{4}$ solution. anocobalamin. Even in the complete system, no activity could be detected in granulocytes of 1 of 11 normal subjects and leukocytes from 1 of $3 \mathrm{CML}$ patients. Two patients with myelomonocytic leukemia (MML) (patients 25 and 26) had methyltransferase activities of 0.63 and 0.58 in the standard assay system, values lower than those of normal lymphocytes. Enzyme activity comparable with that in CLL lymphocytes was found in the leukocytes of patient 23 who had CML in blastic transformation.

With some exceptions serum folate and vitamin $\mathrm{B}_{1 s}$ levels were within the normal range in the patients studied (Table I). Methyltransferase activity in extracts of two CLL patients with low serum folate (patients 6 and 15), with and without added cyanocobalamin, did not differ from levels in patients with normal folate levels.

Characterization of lymphocyte methyltransferase. Kinetic studies were carried out exclusively in CLL cells, normal lymphocytes being scarce and mature granulocytes lacking activity. Substrate and cofactor requirements for methionine biosynthesis in CLL extracts were studied in the experiments summarized in Table III.

There was an absolute requirement for $\beta$-mercaptoethanol. Little activity was detected in the absence of added $\mathrm{CH}_{3}-\mathrm{FH}_{4}$ and SAM. Cyanocobalamin and methylcobalamin were about equally effective in stimulating enzyme activity. Hydroxycobalamin and deoxyadenosylcobalamin were somewhat less effective. The observed $K_{m}$ values for substrates and cofactors in two different 


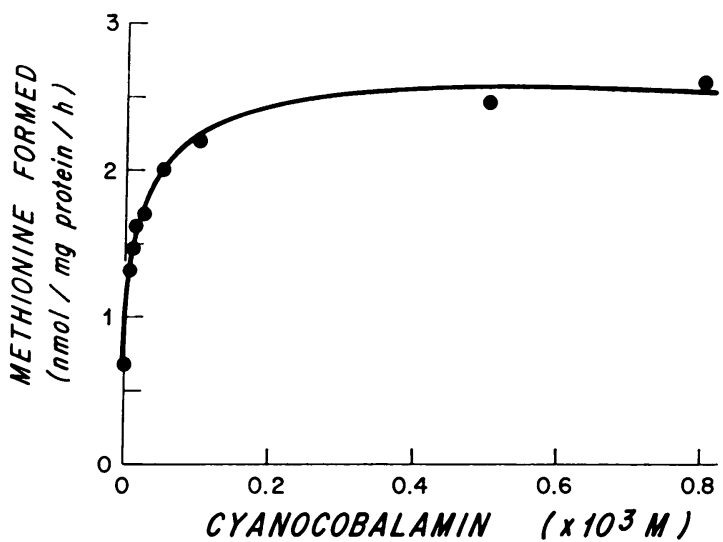

FIGURE 1 Effect of added cyanocobalamin on methyltransferase activity of a pooled extract of CLL lymphocytes. Abscissa, final molarity $\left(\times 10^{3}\right)$ of added cyanocobalamin. Ordinate, methionine formed (nanomoles per milligram protein per hour).

unpooled or pooled CLL extracts were as follows: Lhomocysteine, $0.21 \mathrm{mM}$ (range 0.14-0.28); $\mathrm{CH}_{8}-\mathrm{FH}_{4}$, $0.11 \mathrm{mM}$ (range $0.10-0.13$ ) ; SAM $3.0 \mu \mathrm{M}$ (range $1.5-$ 4.4); and cyanocobalamin $10 \mu \mathrm{M}$ (range, 7-14). The $K_{m}$ for cyanocobalamin fell within the same range when determined from incubations assayed anaerobically.

Since methyltransferase activities in the absence of substrates or cofactors other than cyanocobalamin were below $10 \%$ of the control value of the standard incubation no corrections for this activity were applied in calculating reaction velocities in complete incubations. However, data used in the calculation of the $K_{m}$ for cyanocobalamin were corrected by subtraction of velocities observed without added cyanocobalamin. Thus, the $K_{m}$ of $10 \mu \mathrm{M}$, calculated from velocities in the presence of added cyanocobalamin, is an apparent $K_{m}$ for the dual activity of cyanocobalamin in promoting enzyme activity in vitro. The effect of cyanocobalamin concentration on observed CLL methyltransferase activity is shown in Fig. 1.

Two types of experiments were performed to determine to what extent stimulation by added cobalamin reflected conversion of apoenzyme to holoenzyme, occurrence of which has been demonstrated in bacterial systems $(1,3)$, and to what extent it may have been due to the known capacity of cobalamins to catalyze a nonenzymatic oxidation of thiols that can result in nonspecific enhancement of the reducing atmosphere, the so-called Peel effect (36). In one series of experiments cyanocobalamin was replaced by propylcobalamin, which in bacterial extracts can stimulate methyltransferase activity only by promoting the Peel effect (37). With our extract of $E$. coli B propylcobalamin permitted less than $10 \%$ of the enzyme activity found in the presence of added methylcobalamin. When CLL extract was assayed with propylcobalamin in place of cyanocobalamin there was some stimulation of activity relative to activity without added cobalamin (Table III). The ratio of activity with propylcobalamin relative to that with methylcobalamin was 0.45 , indicating that $45 \%$ of the enzyme was, in fact, present as a holoenzyme (1). This conclusion was supported by experiments showing that when incubations were conducted anaerobically cobalamin-independent holoenzyme activity in CLL extracts was again about half of that observed when cobalamin was present.

When methionine was added to incubation mixtures in final concentrations of $1 \mu \mathrm{M}-10 \mathrm{mM}$ in the presence of saturating concentrations of SAM no inhibition of CLL methyltransferase was detected.

Inhibitors of methyltransferase. The low level of methyltransferase activity in late myeloid cells led to a search for a possible endogenous inhibitor of this enzyme. When myeloid cell extracts were mixed with $E$. coli extract, a marked inhibitory effect was observed with extracts of normal granulocytes and cells from CML (Fig. 2), in striking contrast to the pattern

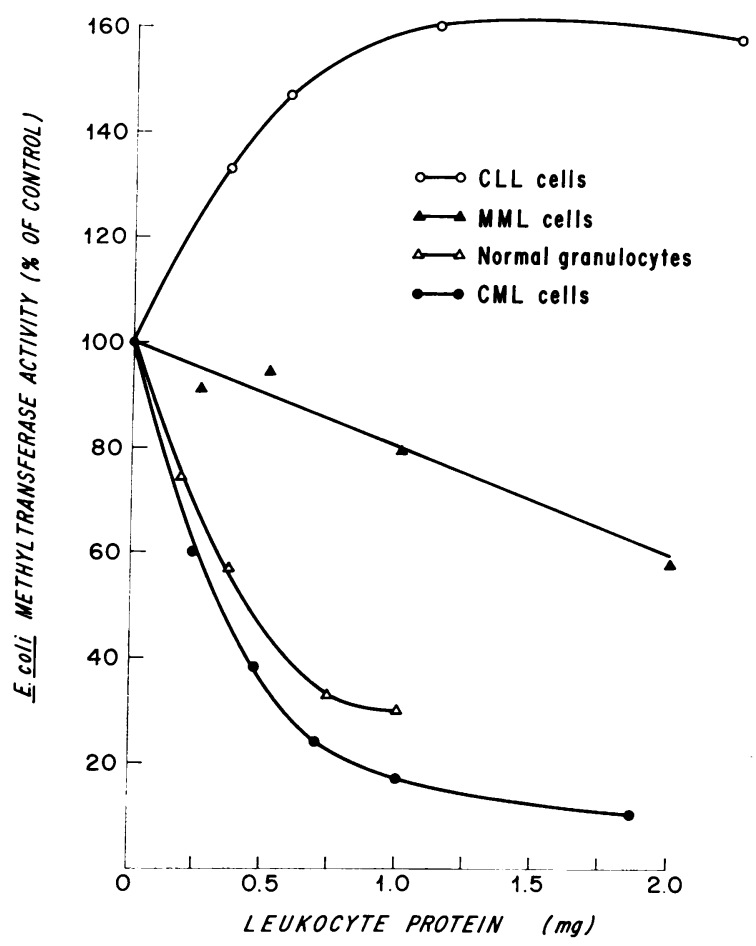

FIGURE 2 Effect upon $E$. coli methyltransferase of pooled extract of granulocytes from normal subjects, extracts of leukocytes from patients with CLL, MML, and CML. Leukocyte extracts containing indicated amounts of protein were added to the incubation mixture with $0.3 \mathrm{mg}$ $E$. coli protein. Activities are expressed as specific activity of $E$. coli methyltransferase relative to $E$. coli control. 
found with extracts of CLL cells and leukemic myeloblasts. Similar results were obtained with $E$. coli extract from bacteria grown in cyanocobalamin. CML extract containing $0.2 \mathrm{mg}$ protein decreased $E$. coli methyltransferase activity to $60 \%$ of its original level, inhibition leveling off at $\mathrm{CML}$ protein concentrations of about $1 \mathrm{mg}$. Pooled granulocyte extracts of two nonleukemic subjects with leukocytosis also depressed $E$. coli methyltransferase as shown in Fig. 2, and were only slightly less inhibitory than extracts of CML cells. When normal granulocyte and CML extracts of diverse origin were repeatedly tested inhibition was invariably present.

To investigate the possibility that inhibition was due to the presence of cobalamin-binding proteins in the granulocyte extract $(38,39)$ increasing amounts of cyanocobalamin were added to standard incubation mixtures. The percent of inhibition of the $E$. coli methyltransferase reaction by normal granulocyte extract $(0.6$ mg of protein) was constant at cyanocobalamin concentrations up to $1.0 \mathrm{mM}$. E. coli enzyme was inhibited by cyanocobalamin concentrations above $1.0 \mathrm{mM}$ without addition of granulocyte extract.

The inhibitor was not dialyzable. Its activity was decreased by 85 and $97 \%$ after heating to $60^{\circ} \mathrm{C}$ for 5 and $15 \mathrm{~min}$, respectively. When soybean trypsin inhibitor was incubated in increasing amounts with a mixture of $E$. coli protein and CML extract, the inhibitory activity of CML cell extract was progressively lost (Table IV). However, increased endogenous methyltransferase activity in CML cells was not detectable

TABLE IV

Effect of Soybean Trypsin Inhibitor on Inhibition of E. coli Methyltransferase by CML Extract*

\begin{tabular}{ccc}
\hline CML protein & $\begin{array}{c}\text { Soybean trypsin } \\
\text { inhibitor }\end{array}$ & $\begin{array}{c}\text { E. coli } \\
\text { methyltransferase } \\
\text { activity }\end{array}$ \\
\hline$m g$ & $m g$ & \% of control \\
0 & 0 & 100 \\
0.6 & 0 & 65 \\
0.6 & 0.08 & 83 \\
0.6 & 0.16 & 86 \\
0.6 & 0.32 & 97 \\
0.6 & 0.8 & 115 \\
0.6 & 1.2 & 118 \\
\hline
\end{tabular}

* CML extract (patient 20, Table I) and soybean trypsin inhibitor were added together in the shown amounts to incubations containing $E$. coli extract $(0.25 \mathrm{mg}$ protein) plus the standard incubation mixture. Patient was receiving busulfan. In a separate control experiment, soybean trypsin inhibitor in the absence of CML extract was shown to have no inhibitory effect on $E$. coli methyltransferase activity. after incubation with soybean trypsin inhibitor. Pancreas trypsin inhibitor had no effect on CML cell inhibitor. CML extracts themselves lacked demonstrable proteolytic activity with casein as substrate.

It is of interest that modest inhibition of CLL methyltransferase by CML extract was noted at low levels of CML protein $(0.2 \mathrm{mg})$. However, activities returned to control levels with further additions of CML extract.

Cell extracts in amounts up to $0.5 \mathrm{mg}$ protein from a patient with MML (patient 25, Table I) was only slightly inhibitory when tested against $E$. coli enzyme. Surprisingly, extracts from a patient with CLL not only failed to inhibit $E$. coli enzyme, but there was a regularly observed stimulation rising in an apparently hyperbolic manner with increasing additions of CLL extracts. In the experiment shown in Fig. 2, the apparent rise in $E$. coli methyltransferase activity after addition of CLL extract reached a maximum of nearly $60 \%$. The possible significance of this result will be the subject of a subsequent report.

\section{DISCUSSION}

The present results confirm the presence of methyltransferase in human leukocytes (12) and show that the enzyme is apparently cobalamin-dependent in lymphoid and myeloid cells. Its other cofactor requirements are also similar to those of methyltransferases from E. coli $(3,4,37,40)$ and various animal cell preparations $(3,5,7,11,41,42)$. Enzyme activity is higher in normal lymphocytes than in granulocytes and is higher still in lymphocytes from patients with CLL. Others $(12,43)$ have found that leukocytic enzyme activity is increased in acute but not chronic leukemias. Since in these experiments lymphocytes were not isolated before preparation of cell extracts, reported normal values cannot be compared directly with the values reported here.

The data raise several points of interest. One concerns the enzymologic properties of leukocyte methyltransferase. Although studied only in unpurified extracts, the enzyme can be readily measured with precision. Activity is substantially stimulated by an added cobalamin derivative, but significant activity remains in the absence of added cobalamins in each of the mononuclear cell types studied. In this respect leukocyte enzyme resembles the methyltransferases of other animal tissues and bacteria $(3,11)$. Since methylcobalamin is a direct participant in the bacterial methyltransferase system (1, 3,40 ), it may be assumed that in the present complete system, cyanocobalamin is reduced by $\beta$-mercaptoethanol to $\mathrm{B}_{12} \mathrm{r}$ which by dismutation becomes $\mathrm{B}_{12} \mathrm{~S}$ which is then methylated by $\mathrm{CH}_{3}-\mathrm{FH}$. The modest stimulation by propylcobalamin, a cobalamin analogue incapable of 
converting apoenzyme to holoenzyme, indicates that about $20 \%$ of the cobalamin stimulation is attributable to the nonenzymatic Peel effect. The increased cobalamin-independent activity in anaerobic conditions has similar implications. This fact, however, does not alter the differences observed in the relative activities of cell types studied. It also does not conflict with the conclusion that most of the stimulation provided by cobalamins is independent of the Peel effect.

The precise biological function of cobalamin in lymphocytes remains a subject for speculation. As noted earlier, this enzyme may generate methionine for protein synthesis or for diverse methyl donor functions or it may provide the $\mathrm{FH}_{4}$ that gives rise to cofactors needed in the synthesis of thymidylate, purine ribonucleotides, or other compounds. There is circumstantial evidence that all these roles might be operative in lymphocytes. In these cells synthesis of proteins, e.g., lymphokines (reviewed in reference 44 ) or immunoglobulins (45), would require a methionine source and possibly a higher methyltransferase level than in granulocytes, where these proteins are not synthesized. In addition lymphocytes display a high proliferative capacity when antigenetically stimulated.

In a number of instances, increased methyltransferase activity can be correlated with accelerated cell division, e.g., in certain phases of lymphoblastic leukemia or during the log phase of growth in phytohemagglutininstimulated lymphocytes (43). Methyltransferase activity has been found to increase in parallel with certain enzymes known to participate in cell division (e.g., DNA polymerase and thymidine kinase) (43). Moreover, methyltransferase activity is higher in bone marrow (the locus of active cell division) than in peripheral blood (12). The present data also show that measurable methyltransferase activity is found in blasts of leukemic myeloid and myelomonocytic lines. Presumably, these cells, too, have a high proliferative potential. It is of interest that all of the cells shown here to contain substantial methyltransferase activity are mononuclear in type.

Investigators of leukocyte metabolism have long been aware that granulocytes are richer in glycolytic and many hydrolytic enzymes than normal and leukemic lymphocytes $(46,47)$. But recent work has shown that in certain respects the enzymatic endowment of lymphocytes is superior to that of granulocytes. For example, normal blood lymphocytes have three to four times the nuclear and cytoplasmic DNA polymerase of granulocytes (48). Also, serine hydroxymethylase is higher in CLL cells than in normal and non-CLL leukocytes (49). The relatively high methyltransferase level in normal and CLL lymphocytes must be added to this list, which presumably reflects the lymphocyte's proliferative potential. It should be noted, however, that this potential (as measured by phytohemagglutinin stimulation) is lower in CLL lymphocytes than in normal ones (50).

Any observed metabolic difference between a normal cell and its neoplastic analogue, especially one in which the neoplastic cell has higher activity than the normal, suggests a possible target for chemotherapeutic attack. Recently, consideration has been given to methionine depletion by means of methioninase as a possible model for cancer therapy $(51,52)$. The fact that methionine depletion in the presence of adequate folate and cobalamin levels increases methyltransferase activity $(7,42$, 53) may be a barrier to the success of such an approach. Moreover, the low methyltransferase activity of mature granulocytes might make them unduly sensitive to the toxic effects of such therapy.

It is difficult to interpret the significance of the apparent inhibitor of $E$. coli methyltransferase in granulocytes until the material is purified and characterized. The present data do not establish the nature of the inhibitory effect which could operate by several mechanisms, among them, (a) inhibition of a labile form of $E$. coli enzyme; (b) inhibition of the conversion of apoenzyme to holoenzyme; $(c)$ direct inhibition of holoenzyme activity; and $(d)$ destruction or competition with methyltetrahydrofolate. It is of interest that granulocytes appear to contain inhibitor and little enzyme activity, while mononuclear cells contain substantial enzyme activity and little inhibitor (Fig. 2). Elimination of inhibitory activity by incubation with a trypsin inhibitor suggests that one or more proteolytic enzymes of later myeloid cells may be part of the inhibitory effect. The possibility also arises that certain, possibly protein-bound, cobalamin derivatives inhibitory to methyltransferase might be present $(54,55)$, especially in view of the high levels of cobalamin (56), and cobalamin-binding proteins $(38,39)$ in myeloid cells. The biochemical mechanism of inhibition and insight into whether or not the apparent inhibitor of methyltransferase in myeloid cells has physiologic significance and indeed whether it has a role in suppressing the activity of endogenous enzymes will be subjects for further research.

\section{ACKNOWLEDGMENTS}

The authors are pleased to acknowledge the scientific advice of our colleague Dr. Chitra Biswas, the fine assistance of Jean Frankenfeld and Ann Marie Bitzer in the performance of serum vitamin $B_{12}$ and folate assays, and the cooperation of many hematologists at the Massachusetts General Hospital and Peter Bent Brigham Hospital for placing clinical material at our disposal. The manuscript was prepared by Mary Ochs and Denise Baldassarre.

${ }^{2}$ Peytremann, R. Unpublished observations. 
This investigation was supported by U. S. Public Health Service Research grant CA-03728 from the National Cancer Institute and by the John Phyffe Richardson Fund.

\section{REFERENCES}

1. Taylor, R. T., and H. Weissbach. 1967. $\mathrm{N}^{5}$-methyltetrahydrofolate-homocysteine transmethylase. Propylation characteristics with the use of a chemical reducing system and purified enzyme. J. Biol. Chem. 242: 1509-1516.

2. Guest, D. R., C. W. Helleiner, M. J. Cross, and D. D. Woods. 1960. Cobalamin and the synthesis of methionine by ultrasonic extracts of Escherichia coli. Biochem. J. $76:$ 396-405.

3. Weissbach, H., A. Peterkofsky, B. G. Redfield, and H. Dickerman. 1963. Studies on the terminal reaction in the biosynthesis of methionine. J. Biol. Chem. 238: 3318-3324.

4. Stavrianopoulos, J., and L. Jaenicke. 1967. Reaktionsschritte der Methionin-synthese bei Echerichia coli. Eur. J. Biochem. 3: 95-106.

5. Dickerman, H., B. G. Redfield, J. G. Bieri, and $\mathrm{H}$. Weissbach. 1964. The role of vitamin $B_{12}$ in methionine biosynthesis in avian liver. J. Biol. Chem. 239: 25452552.

6. Loughlin, R. E., H. L. Elford, and J. M. Buchanan. 1964. Enzymatic synthesis of the methyl group of methionine. VII. Isolation of a cobalamin-containing transmethylase (5-methyltetrahydrofolate-homocysteine) from mammalian liver. J. Biol. Chem. 239: 2888-2895.

7. Mangum, J. H., B. K. Murray, and J. A. North. 1969. Vitamin $\mathrm{B}_{12}$ dependent methionine biosynthesis in cultured mammalian cells. Biochemistry. 8: 3496-3499.

8. Mudd, S. H., B. W. Uhlendorf, and K. R. Hinds. 1970. Deranged $B_{12}$ metabolism: studies of fibroblasts grown in tissue culture. Biochem. Med. 4: 215-239.

9. Mangum, J. H., and J. A. North. 1971. Isolation of a cobalamin containing 5-methyltetrahydrofolate-homocysteine transmethylase from mammalian kidney. Biochemistry. 10: 3765-3769.

10. Mangum, J. H., B. W. Steuart, and J. A. North. 1972. The isolation of $\mathrm{N}^{5}$-methyltetrahydrofolate-homocysteine transmethylase from bovine brain. Arch. Biochem. Biophys. 148: 63-69.

11. Sauer, H-J., and L. Jaenicke. 1972. Einfacher Test zur Messung der Methionin-Synthetase-(MS)-Activität und seine Anwendungsmöglichkeit in der Klinik. Klin. Wochenschr. 50: 986-990.

12. Bloos, I., and H-J. Sauer. 1972. Nachweis und Aktivität der Methioninsynthetase in normalen and pathologischen Zellen des Blutes und des Knochenmarks. Klin. Wochenschr. 50 : 991-994.

13. Gaull, G. E., W. von Berg, N. C. R. Räihä, and J. A. Sturman. 1973. Development of methyltransferase activities of human fetal tissues. Pediatr. Res. 7 : 527-533.

14. Ashe, H., B. R. Clark, F. Chu, D. N. Hardy, B. C. Halpern, R. M. Halpern, and R. A. Smith. 1974. $\mathrm{N}^{5}-$ methyltetrahydrofolate: homocysteine methyltransferase activity in extracts from normal, malignant and embryonic tissue culture cells. Biochem. Biophys. Res. Commun. 57 : 417-425.

15. Taylor, R. T., M. L. Hanna, and J. J. Hutton. 1974. 5-methyltetrahydrofolate homocysteine cobalamin methyltransferase in human bone marrow and its relationship to pernicious anemia. Arch. Biochem. Biophys. 165: 787-795.
16. Norohna, J. M., and M. Silverman. 1962. On folic acid, vitamin $\mathrm{B}_{12}$, methionine and formiminoglutamic acid metabolism. Vitamin $\mathrm{B}_{12}$ und Intrinsic Factor, 2d Europäisches Symposium. H. C. Heinrich, editor. Ferdinand Enke Verlag, Stuttgart. 728-736.

17. Beck, W. S. 1975. Metabolic features of cobalamin deficiency in man. In Cobalamin: Biochemistry and Biochemical Pathology. B. M. Babior, editor. John Wiley \& Sons, Inc., New York. 403-450.

18. Das, K. C., and A. V. Hoffbrand. 1970. Lymphocyte transformation in megaloblastic anemia: morphology and DNA synthesis. Br. J. Haematol. 19: 459-468.

19. Van Dommelen, C. K. V, G. Slagboom, G. T. Meester, and S. K. Wadman. 1963. Reversible hypogammaglobulinemia in cyanocobalamin $\left(\mathrm{B}_{12}\right)$ deficiency. Acta Med. Scand. 174 : 193-200.

20. Kiossoglou, K. A., W. J. Mitus, and W. Dameshek. 1965. Chromosomal aberrations in pernicious anemia. Study of three cases before and after therapy. Blood. 25 : $662-682$.

21. Lawler, S. D., P. D. Roberts, and A. V. Hoffbrand. 1971. Chromosomal studies in megaloblastic anaemia before and after treatment. Scand. J. Haematol. 8: 309-320.

22. Dolphin, D. 1971. Preparation of the reduced forms of vitamin $B_{12}$ and of some analogues of the vitamin $B_{12}$ coenzyme containing a cobalt-carbon bond. Methods Enzymol. 18 ( Pt. C) : 34-52.

23. Blair, J. A., and K. J. Saunders. 1970. A convenient method for the preparation of $d l-5$-methyltetrahydrofolic acid (dl-5-methyl-5,6,7,8-tetrahydropteroyl-L-monoglutamic acid). Anal. Biochem. 34: 376-381.

24. Gupta, V. S., and F. M. Huennekens. 1967. Preparation and properties of crystalline 5-methyl tetrahydrofolate and related compounds. Arch. Biochem. Biophys. 120: 712-718.

25. Shapiro, S. K. 1971. S-adenosylmethionine: L-homocysteine S-methyl-transferase (Saccharomyces cerevisae). Methods Enzymol. 17 (Pt. B) : 400-405.

26. Baker, H., V. Herbert, O. Frank, I. Pasher, S. H. Hutner, L. R. Wasserman, and H. Sobotka. 1959. A microbiologic method for detecting folic acid deficiency in man. Clin. Chem. $5: 275-280$.

27. Rosenthal, H. L., and H. P. Sarett. 1952. The determination of vitamin $B_{12}$ activity in human serum. $J$. Biol. Chem. 199 : 433-442.

28. Skoog, W. A., and W. S. Beck. 1956. Studies on the fibrinogen, dextran and phytohemagglutinin methods of isolating leukocytes. Blood. 11: 436-454.

29. Böyum, A. 1968. Isolation of mononuclear cells and granulocytes from human blood. Scand. J. Clin. Lab. Invest. 21 (Suppl. 97) : 77-89.

30. Handin, R. I., W. F. Piessens, and W. S. Moloney. 1973. Stimulation of nonimmunized lymphocytes by platelet-antibody complexes in idiopathic thrombocytopenic purpura. N. Engl. J. Med. 289: 714-718.

31. Davis, B. D., and E. S. Mingioli. 1950. Mutants of Escherichia coli requiring methionine or vitamin $B_{12}$. J. Bacteriol. $60: 17-28$.

32. Taylor, R. T., and H. Weissbach. 1967. $\mathrm{N}^{5}$-methyltetrahydrofolate-homocysteine transmethylase. Role of S-adenosylmethionine in vitamin $\mathrm{B}_{12}$-dependent methionine synthesis. J. Biol. Chem. 242: 1517-1521.

33. Lineweaver, H., and D. Burk. 1934. The determination of enzyme dissociation constants. J. Am. Chem. Soc. 56 : $658-666$. 
34. Laskowski, M. 1955. Trypsinogen and trypsin. Methods Enzymol. 2: 26-36.

35. Zamenhof, S. 1957. Preparation and assay of deoxyribonucleic acid from animal tissue. Methods Enzymol. 3: 696-704.

36. Peel, J. L. 1962. Vitamin $\mathrm{B}_{12}$ derivatives and the $\mathrm{CO}_{2-}$ pyruvate exchange reaction: a reappraisal. J. Biol. Chem. 237 : PC263-PC265.

37. Weissbach, H., B. Redfield, and H. Dickerman. 1964. Cobamide-dependent synthesis of methionine: light reactivation of an inhibited enzyme. Biochem. Biophys. Res. Commun. 17 : 17-22.

38. Meyer, L. M., E. P. Cronkite, I. F. Miller, C. W. Mulzac, and I. Jones. 1962. $\mathrm{Co}^{80}$ vitamin $\mathrm{B}_{12}$ binding capacity of human leukocytes. Blood. 19: 229-235.

39. Simons, K., and T. Weber. 1966. The vitamin $B_{12}$-binding protein in human leukocytes. Biochim. Biophys. Acta. 117: 201-228.

40. Taylor, R. T., and H. Weissbach. 1969. Escherichia coli B N $\mathrm{N}^{5}$-methyltetrahydrofolate-homocysteine cobalamin methyltransferase: activation with S-adenosyl-Lmethionine and the mechanism for methyl group transfer. Arch. Biochem. Biophys. 129: 745-766.

41. Kerwar, S. S., C. Spears, B. McAuslan, and H. Weissbach. 1971. Studies on vitamin $B_{12}$ metabolism in HeLa cells. Arch. Biochem. Biophys. 142: 231-237.

42. Kameley, D., J. W. Littlefield, and R. W. Erbe. 1973. Regulation of 5-methyltetrahydrofolate: homocysteine methyltransferase activity by methionine, vitamin $B_{12}$, and folate in cultured baby hamster kidney cells. Proc. Natl. Acad. Sci. U. S. A. 70: 2585-2589.

43. Sauer, H-J., K. Wilms, W. Wilmanns, and L. Jaenicke. 1973. Die Aktivität der Methionin-synthetase (5-Methyl5, 6, 7, 8-tetrahydrofolsäure: Homocystein Methyltransferase) als Proliferationsparameter in wachsenden Zellen. Acta Haematol. (Basel). 49: 200-210.

44. Valentine, F. T. 1974. Soluble factors produced by lymphocytes. Ann. N. Y. Acad. Sci. 221: 317-323.

45. Kaltreider, H. B., and S. E. Salmon. 1973. Immunology of the lower respiratory tract. Functional properties of bronchoalveolar lymphocytes obtained from the normal canine lung. J. Clin. Invest. 52: 2211-2217.
46. Beck, W. S. 1958. The control of leukocyte glycolysis. J. Biol. Chem. 232: 251-270.

47. Beck, W. S., and W. N. Valentine. 1951. Biochemical studies on leukocytes. II. Phosphatase activity in chronic lymphatic leucemia, acute leucemia, and miscellaneous hematologic conditions. J. Lab. Clin. Med. 38: 245-253.

48. Coleman, M. S., J. J. Hutton, and F. J. Bollum. 1974. DNA polymerases in normal and leukemic human hematopoietic cells. Blood. 44 : 19-32.

49. Bertino, J. R., R. Silber, M. Freeman, A. Alenty, M. Albrecht, B. W. Gabrio, and F. M. Huennekens. 1963. Studies on normal and leukemic leukocytes. IV. Tetrahydrofolate-dependent enzyme systems and dihydrofolic reductase. J. Clin. Invest. 42: 1899-1907.

50. Perera, D. J. B., and G. D. Pegrum. 1974. In vitro stimulation of chronic lymphocytic leukaemic lymphocytes. Br. J. Haematol. 27 : 289-296.

51. Kreis, W., and C. Hession. 1973. Biological effects of enzymatic deprivation of L-methionine in cell culture and an experimental tumor. Cancer Res. 33: 1866-1869.

52. Halpern, B. C., B. R. Clark, D. N. Hardy, R. M. Halpern, and R. A. Smith. 1974. The effect of replacement of methionine by homocysteine on survival of malignant and normal adult mammalian cells in culture. Proc. Natl. Acad. Sci. U. S. A. 71: 1133-1136.

53. Finkelstein, J. D., W. E. Kyle, and B. J. Harris. 1971. Methionine metabolism in mammals. Regulation of homocysteine methyltransferases in rat tissue. Arch. Biochem. Biophys. 146: 84-92.

54. Guest, J. R. 1960. Inhibition of methionine synthesis in Escherichia coli by analogues of cobalamin. Biochem.J. 76: 405-412.

55. Weissbach, H., B. G. Redfield, and H. Dickerman. 1964. Effect of vitamin $B_{12}$ analogues on methionine formation from $\mathrm{N}^{\mathrm{5}}$-methyltetrahydrofolic acid. J. Biol. Chem. 239: $146-148$

56. Rachmilewitz, M., F. Lefton, and J. Gross. 1966. Vitamin $B_{12}$ content of cells of the blood, bone marrow and liver of the rat. Proc. Soc. Exp. Biol. Med. 121: 10471049. 